Physical Laboratory (Deuce and Ace), Ferranti (Pegasus and Sirius), Elliot Brothers, Cambridge University Mathematical Laboratory (Edsac II), E.M.I. Electronics (Emidec), London University Computational Laboratory (Mercury), Creeds (project high-speed punching), Solatron (Era), Leo Computers and International Computers and Tabulators. The fee for the course is $£ 47$ and accommodation will be in London hotels.

\section{Radioisotopes in Agricultural Research}

A REgIONAL training course on the use of radioisotopes in agricultural research, organized jointly by the Ministry of Food and Agriculture, Government of India, Food and Agriculture Organization, International Atomic Energy Agency and Unesco South Asia Science Co-operation Office, will be held at the Indian Agricultural Research Institute, New Delhi, during January 20-February 17, 1960. The course will deal with the role of radiation in cytology and genetics, radioisotope techniques as applied to problems in soil fertility, fertilizer application and plant biochemistry and radiation as a protective agent. Unesco has extended invitations to the Governments of Burma, Ceylon, India, Pakistan and Thailand. A maximum of twenty-five participants will be admitted to the course. Further information can be obtained from the Unesco South Asia Science Co-operation Office, 21 Curzon Road, New Delhi, India.

\section{The Night Sky in December}

FuLL moon occurs on Dec. 15d. 04h. 49m. U.T and new moon on Dec. $29 \mathrm{~d} .19 \mathrm{~h} .09 \mathrm{~m}$. The following conjunctions with the Moon take place: Dec. 2d. 06h., Saturn $4^{\circ} \mathrm{S}$. ; Dec. 26d. 19h., Venus $2^{\circ} \mathrm{S}$. In addition to these conjunctions with the Moon, Mars is in conjunction with Antares on Dec. 15d. 16h., Mars being $4 \cdot 4^{\circ}$ N., Mercury with Antares on Dec. $20 \mathrm{~d}$. 08h., Mercury being $6 \cdot 0^{\circ} \mathrm{N}$., Mercury with Mars on Dec. 25d. 13h., Mercury being $1 \cdot 0^{\circ}$ N., Mercury with Jupiter on Dec. 27d. 01h., Mercury being $0.0^{\circ} \mathrm{S}$., and Mars with Jupiter on Dec. 29d. 01h., Mars being $0.8^{\circ} \mathrm{S}$. Mercury will be visible as a morning star during the first three weeks of the month, rising almost two hours before the Sun, but conditions are not particularly favourable. Venus is a morning star, rising at $3 \mathrm{~h} .25 \mathrm{~m}$., $4 \mathrm{~h}$. $00 \mathrm{~m}$. and $4 \mathrm{~h} .40 \mathrm{~m}$. on December 1,15 and 31 , respectively; its stellar magnitude is $-\mathbf{3} \cdot 8$. Its distance increases during the month from 77 to 98 million miles and the visible portion of the apparent disk increases from 0.598 to 0.714 . Mars, Jupiter and Saturn are too close to the Sun for observation. Occultations of stars brighter than magnitude 6 are as follows, observations being made at Greenwich : Dec. 13d. 22h. 10.3m., 75 Tau. $(D)$; Dec. 20d. 6h. $09 \cdot 4 \mathrm{~m}$., O Leo. $(D)$; Dec. 20 d. $7 \mathrm{~h} .12 \cdot 6 \mathrm{~m}$., O Leo. $(R)$; Dec. 27 d. 6h. 34.1m., $\theta$ Lib. $(R) ; D$ and $R$ refer to disappearance and reappearance, respectively. The Geminid meteors are active during December 9-14 and the Ursids during December 20-22, but in neither case are conditions favourable for observation. The winter solstice occurs on Dec. 22d. 15h.

University News :

London

Dr. G. Monton, lecturer at the London School of Economics and Political Science, has been appointed to the University readership in operational research tenable at that School.

Titles have been conferred as follow : professor of embryology on Mr. Michael Abercrombie, reader in chemistry on Dr. D. J. Millen, reader in botany on Mr. P. J. Syrett, in respect of their posts at University College.

Sheffield

THE following appointments to lectureships have been announced: E. Litton (civil engineering); L. G. M. Sparling (mechanical engineering).

\section{Announcements}

THE firm of Blackie and Son, Ltd., has celebrated its 150th year of publishing. Until very recently, all the scientific and technical publishing was conducted from Glasgow, but now a publishing department has been set up at the firm's London office to handle this type of book, and Mr. Christopher T. Rivington has been appointed London scientific editor.

Mr. A. S. D. Barratr, technical director of Edwards High Vacuum, Ltd., since 1945, is resigning from the board of the Company at the end of the year to become an independent consultant. His long association with the Company will, however, be maintained by his appointment as technical consultant to the Company, thus providing a liaison between the large-scale developments of vacuum technology now taking place and the long-term developments of the Edwards international group of companies.

ThE Iron and Steel Institute is devoting the main sessions at its autumn general meeting during December 2-3 to the forging and extrusion of steel. The meeting is being held in the Great Hall, Caxton Hall, London. Further information can be obtained from H. Cleere, Iron and Steel Institute, 4 Grosvenor Gardens, S.W.1.

A symposium on the Exploitation of Natural Animal Populations, sponsored by the British Ecological Society, will be held at the Durham Colleges, University of Durham, during March 28-3I. Full details can be obtained from E. D. Le Cren, The Ferry House, Ambleside, Westmorland.

ThE University of Texas M.D. Anderson Hospital and Tumour Institute announces the fourteenth Annual Symposium on Fundamental Cancer Research, "Cell Physiology of Neoplasia", to be held during February 25-27. Further information can be obtained from the Editorial Office, The University of Texas M.D. Anderson Hospital, Texas Medical Center, Houston 25, Texas.

THE Department of Civil Engineering and the Department of Extra-Mural Studies in the University of Birmingham have announced a course on River Pollution Sewage Disposal and Trade Waste Treatment, to be held at the University of Birmingham during January 4-8, 1960, and continued during April 4-8, 1960. The course is arranged in cooperation with the Institute of Sewage Purification. Further information can be obtained from Mr. R. F. Wills, Civil Engineering Department, The University, Edgbaston, Birmingham 15.

Further to the announcement in the September 19 issue of Nature regarding the availability of the "Great Soviet Encyclopædia" in Britain, a complete translation into English of the fiftieth volume of the second edition will be published by Pergamon Press, Ltd., early in 1960 under the title of "U.S.S.R. Information". This is an authorized translation, produced with the full co-operation of the editorin-chief of the "Great Soviet Encyclopædia". 